\title{
Determination of Cytotoxic and Anticandidal Activities of Three Verbascum L. Species from Turkey: V. cheiranthifolium Boiss. var. asperulum (Boiss.) Murb. Monorg., $V$. pycnostachyum Boiss. \& Heldr and V. orgyale Boiss. \& Heldr
}

Türkiye'den Üç Verbascum L. Türünün Sitotoksik ve Antikandidal Aktivitelerinin Belirlenmesi; Verbascum cheiranthifolium Boiss. var. Asperulum (Boiss.) Murb. Monorg., Verbascum pynostachyum Boiss. \& Heldr ve Verbascum orgyale Boiss. \& Heldr

Sevim KÜÇÜK1*, Filiz ÖZDEMiR², Gökalp IŞCAN³, Zerrin INCESU2

1Anadolu University, Faculty of Pharmacy, Department of Pharmaceutical Botany, Eskișehir, TURKEY

2Anadolu University, Faculty of Pharmacy, Department of Biochemistry, Eskișehir, TURKEY

${ }^{3}$ Anadolu University, Faculty of Pharmacy, Department of Pharmacognosy, Eskișehir, TURKEY

\begin{abstract}
Purpose of this study is to determine of cytotoxic and anticandidal activities of Verbascum cheiranthifolium Boiss. var. asperulum (Boiss.) Murb. Monorg., Verbascum pynostachyum Boiss. \& Heldr and Verbascum orgyale Boiss. \& Heldr belonging to Verbascum genus growing in Turkey. The cytotoxic effects of methanolic extract of Verbascum cheiranthifolium var. asperulum, $V$. pycnostachyum and $V$. orgyale species on the cervical ( $\mathrm{HeLa}$ ) and ovarian cancer (Skov-3) cells were investigated using colorimetric assay. The results indicated that methanolic-extract of $V$. pycnostachyum had a promising toxic effect on both cell lines as compared to the other species. Furthermore, this effect was more significant on Skov-3 cells rather than HeLa cells. Anticandidal effects of the methanolic extracts were evaluated in comparison with standard antifungal agents according to Clinical Laboratory Standards Institute (CLSI) reference methods, for the first time here. V. pynostactum and V. orygale extracts were demonstrated stronger inhibitory effects than the $V$. cheriantifolium var. asperulum. Remarkably, Candida krusei was inhibited by $V$. pycnostachyum extract at the concentration of the $62.5 \mu \mathrm{g} / \mathrm{mL}$.
\end{abstract}

Key words: Scrophulariaceae, Verbascum, Cytotoxicity, Anticandidal activities

ÖZ

Bu çalıșmada Türkiye'de yetișen Verbascum L. cinsine ait üç türün; Verbascum cheiranthifolium Boiss. var. asperulum (Boiss.) Murb. Monorg., V. pycnostachyum Boiss. \& Heldr, ve V. orgyale Boiss. \& Heldr. türlerinin sitotoksik ve antikandidal aktivitelerinin belirlenmesi amaçlanmıştır. Verbascum cheiranthifolium var. asperulum, V. pycnostachyum and $V$. orgyale türlerinin metanol ekstrelerinin sitotoksik etkileri servikal (HeLa) ve ovaryum kanser (Skov-3) hücrelerinde kolorimetrik metod kullanılarak araştırılmıştır. Elde edilen sonuçlar; V. pycnostachyum türünün metanol ekstresinin diğer türlere oranla her iki hücre hattında da umut verici toksik etkiye sahip olduğu gösterilmiștir. Buna ek olarak; bu etki Skov-3 hücrelerinde HeLa hücrelerine kıyasla daha anlamlıdır. Üç türe ait metanol ekstresinin antikandidal etkileri "Klinik Laboratuvar Standartları Enstitüsü" (CLSI)'nün mikrodilüsyon standart protokolleri kullanılarak standart antifungal ajanlarla karlılaştırmalı şekilde ilk kez bu çalışma ile ortaya konmuștur. V. pycnostachyum ve V. orygale ekstreleri $V$. cheriantifolium'a göre daha kuvvetli inhibitör etkiler göstermiștir. Verbascum pycnostachyum ekstresi dikkat çekici olarak Candida krusei'yi, $62.5 \mathrm{~g} / \mathrm{mL}$ konsantrasyonda inhibe etmiștir.

Anahtar kelimeler: Scrophulariaceae, Verbascum, Sitotoksisite, Antikandidal aktivite 


\section{INTRODUCTION}

Verbascum L. (1753: 177) (Scrophulariaceae) includes about 360 species throughout world (1). In Turkey, with the additional 130 hybrids, the genus is represented by 246 species, 6 imperfectly known or doubtful records (2-5). The endemism ratio (80\%) of the genus is very high with 196 endemic species $(4,5)$.

In Turkey, the species $V$. cheiranthifolium var. asperulum, $V$. pycnostachyum and V. orgyale known as "Bozkulak", "Eğirdir sığır kuyruğu" and "Söke sığır kuyruğu" respectively $(2,4)$.

Many plant species among the flora of Turkey play an important role in traditional medicine. There are approximately 9000 plant species, some of them are widely used in folkloric medicine due to their antimicrobial and anticarcinogenic properties, in Turkish flora (6,7). One of the well-known Verbascum species is $V$. thapsus L., which has been used for the treatment of several diseases including asthma, spasmodic cough, migraine and earache. Moreover, V. thapsus, V. fruticulosum $V$. undulatum and $V$. georgicum had anti-malarial and antiviral effects that were investigated by both in vitro and in vivo studies (6).

It is reported that leaves and flowers of Verbascum species have expectorant, mucolytic and demulcent properties, and they are used to treat respiratory disorders such as bronchitis, dry coughs, tuberculosis, asthma in Anatolia $(8,9)$. Verbascum species are also used to treat hemorrhoids, rheumatic pain, superficial fungal infections, wounds and diarrhea. Furthermore these species demonstrate several inhibitory activities against the murine lymphocytic leukemia and influenza viruses A2 and B. Macerated oil prepared from the flowers is used for reducing earache, applied externally for eczema and other types of inflammatory skin disorders (10).

Verbascum species have some folkloric usages such as sedative and treatment of dysmenorrhoea and rheumatalgia. It was also notified the usage for healing wounds in animal care.

Iridoid and neolignan type glycosides, oleanan type terpenes, flavonoids, polysaccharides, saponins, steroids and alkaloids were major compounds isolated from Verbascum species (11). In several bioactivity studies on Verbascum sp. reported that crude extracts of roots, leaves, flowers and aerial parts have been shown anti-proliferative (12), anti-inflammatory (13), antioxidant (14,15), anti-histaminic, anti-fungal, anti-bacterial, (16), wound healing (17), anti-microbial (18) and anti-cancer effects (19).

In the present study, three species belonging to Verbascum genus, were evaluated for their cytotoxic (on cervical and ovarian cancer cell lines) and anticandidal effects for the first time.

\section{EXPERIMENTAL}

\section{Plant materials}

The plant materials were collected from following localities; Verbascum cheiranthifolium var. asperulum B3 Eskișehir, Bozdağ region, 18.6.2014, 39 53' 24" K - 030 33" 16" D, 1267 m, (ESSE:14686); Verbascum pycnostachyum C3: Antalya, Korkuteli-Fethiye region, 37 02' 53" N, 30 06' 26", 1370 m, 20.06.2007, ESSE 14730 (AKDU 6093) and Verbascum orgyale C3:Antalya: Antalya-Geyikbayırı region, 36 52' 41" N 30²6' 37" E, 1008 m, 15.07.2007, (ESSE 14622, AKDU 6064) in Turkey. Voucher specimens are deposited in the Herbarium of the Faculty of Pharmacy (ESSE), Anadolu University in Eskişehir and Herbarium of the Biology Department, Akdeniz University in Antalya, Turkey (AKDU).

\section{Extraction}

Air dried plant materials were macerated with $70 \% \mathrm{MeOH}$ (MERCK) at $25^{\circ} \mathrm{C}$ for $24 \mathrm{~h}$ on orbital shaker. After evaporation and lyophilization steps the dry extract was kept at $+4^{\circ} \mathrm{C}$ until bioactivity studies.

\section{Cell culture}

The human cervical adenocarcinoma cells (HeLa) were maintained in Eagle's Minimum Essential Medium (EMEM) (Sigma-Aldrich, UK) supplemented with 20\% Fetal Bovine Serum (FBS) (Gibco, UK), 1\% penicillin-streptomycin and $4 \%$ sodium bicarbonate as adherent monolayers. The human ovarian adenocarcinoma cells (Skov-3) were cultured in Dulbecco's Modified Eagle Medium (DMEM) (SigmaAldrich, UK) supplemented with 10\% FBS and 1\% penicillinstreptomycin. The cell lines were routinely subcultured using $0.25 \%$ tripsin-EDTA solution (Sigma-Aldrich, UK).

Stock solution of extract of Verbascum sp. were prepared in sterile $\mathrm{ddH}_{2} \mathrm{O}$ and that was diluted in culture medium to prepare final concentrations of extracts. The cells were incubated with each Verbascum sp. $(0,1-3 \mathrm{mg} / \mathrm{mL})$ for 24 hours at $37^{\circ} \mathrm{C}(20)$.

\section{Cell viability assay}

MTT[3-(4,5-dimethylthiazol-2-yl)-2,5-diphenyl-2H-tetrazolium bromide] is a non-radioactive assay and measures the reduction of yellow MTT by mitochondrial succinate dehydrogenase. The reduction of MTT can only occur in metabolically active cells. The assay was performed as mentioned in Mossman. HeLa and Skov- 3 cells $\left(2 \times 10^{4}\right)$ were seeded in 96-well plates in the presence and absence of different concentrations of Verbascum sp. for 24 hours at at $37^{\circ} \mathrm{C}$ in a $5 \% \mathrm{CO}_{2} / 95 \%$ air atmosphere. After incubation time, $20 \mathrm{ml}$ of MTT $(5 \mathrm{mg} / \mathrm{mL}$ ) was added to each well and the cells were incubated for a further 2 hours. The reduction of MTT was measured by ELISA (ELX $808 \mathrm{IU})$ reader at a wavelength of $540 \mathrm{~nm}$.

Viability $(\%)=($ Absorbance of the treated cells) / (Absorbance of the control wells) $\times 100$. Each concentrations was tested in two different experiments run in triplicate. 


\section{Anticandidal activity}

Anticandidal activities of the methanolic extracts were evaluated by partly modified reference method of Clinical and Laboratory Standards Institute (CLS/) M27-A2 (21).

Candida albicans ATCC 90028, C. utilis NRRL Y-900, C. glabrata ATCC 66032, C. tropicalis ATCC 750, C. parapsilosis ATCC 22019 and C. krusei ATCC 6258 were used as pathogenic test microorganisms. Stock cultures stored in

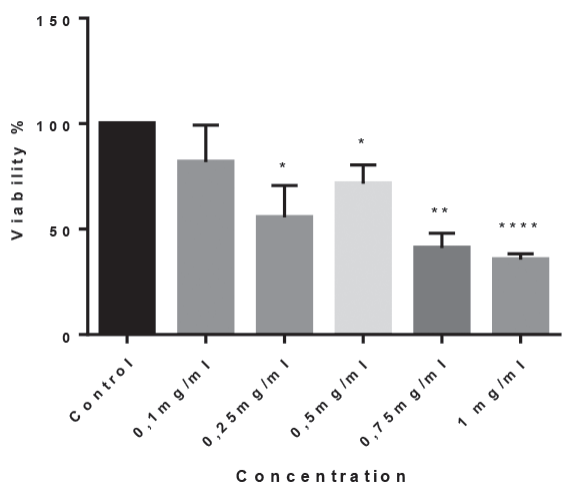

Verbascum pycnostochyum (A)

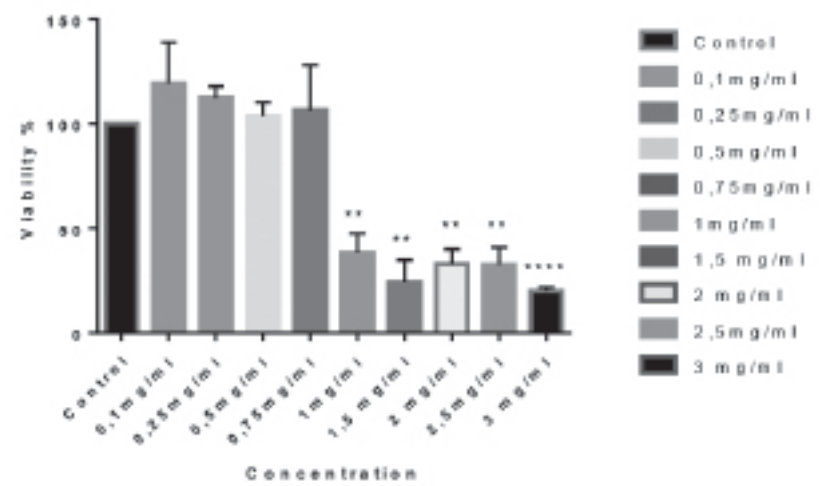

Verbascum cheiranthifolium var. asperulum (B)

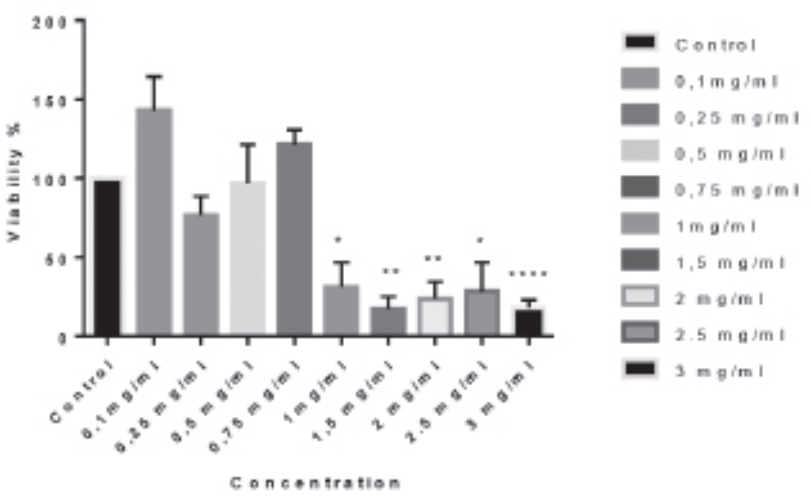

Verbascum orgyale (C)

Figure 1. Treatment of either $V$. pycnostachyum, $V$. cheiranthifolium var. asperulum or $V$. orgyale extracts with HeLa cells decreased the cell viability in a dose-dependent manner. Bars indicate mean \pm standard deviation. All comparisons were made relative to untreated control cells. The significant differences were indicated as $p<0.05$ using one-way ANOVA. The graphic was created by using GraphPad Prism 6 software. [ ${ }^{*} p<0.1 ;{ }^{*} p<0.01$; $* \star * * x<0.001]$.
$50 \%$ glycerol at $-85^{\circ} \mathrm{C}$, were inoculated in Mueller Hinton Agar (Acumedia) plates and incubated at $37^{\circ} \mathrm{C}$ for $24 \mathrm{~h}$ for checking purity and viability. After incubation, selected colonies were suspended in $0.85 \% \mathrm{NaCl}$ solution and adjusted to McFarland No: 0.5. Serial dilutions of the extracts were prepared in range of 4000 to $7 \mu \mathrm{g} / \mathrm{mL}$. After incubation at $37^{\circ} \mathrm{C}$ for $24 \mathrm{~h}$, MIC values was determined by visual reading of wells without growing. Amphotericin B (Sigma) and Ketoconazole (Sigma) were used as standard antifungal agents.

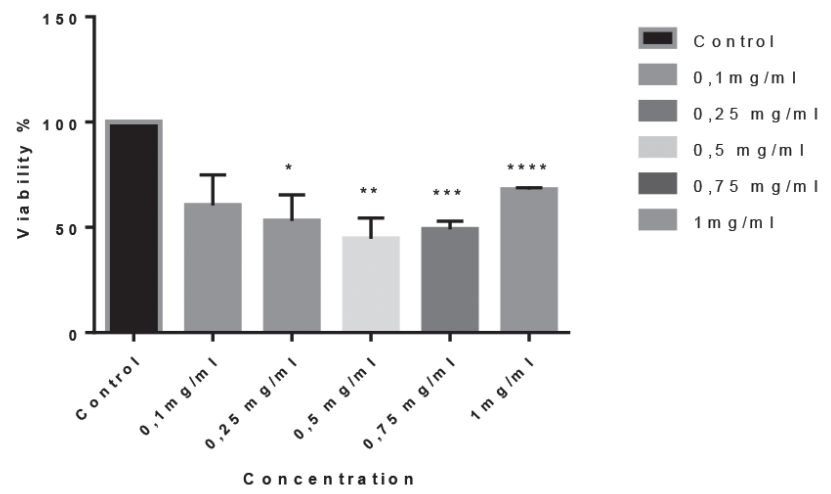

Verbascum pycnostochyum (A)

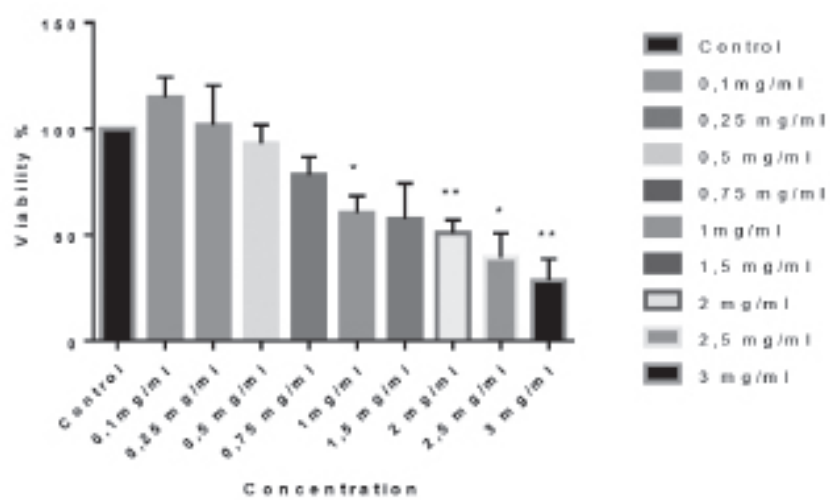

Verbascum cheiranthifolium var. asperulum (B)

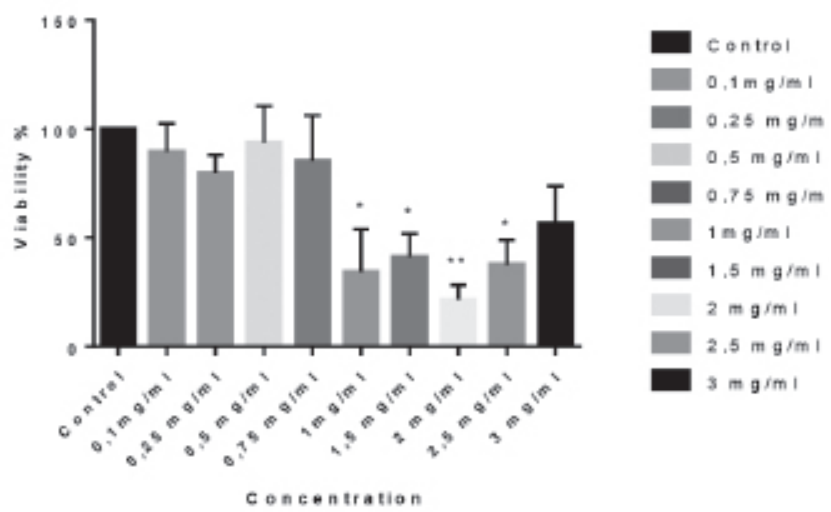

Verbascum orgyale (C)

Figure 2. The percentage of cell viability after treating Skov-3 cells with either $V$. pycnostachyum, $V$. cheiranthifolium var. asperulum or $V$. orgyale methanolic-extract. Bars indicate mean \pm standard deviation. All comparisons were made relative to untreated control cells. The significant differences were indicated as $p<0.05$ using one-way ANOVA. The graphic was created by using GraphPad Prism 6 software. [ ${ }^{*} p<0.1$; ${ }^{* *} p<0.01$; $\star * * * p<0.001]$. 


\begin{tabular}{|c|c|c|c|c|c|c|}
\hline & $\begin{array}{l}\text { C. } \\
\text { albicans }\end{array}$ & $\begin{array}{l}\text { C. } \\
\text { tropicalis }\end{array}$ & $\begin{array}{l}\text { C. } \\
\text { parapsilosis }\end{array}$ & $\begin{array}{l}\text { C. } \\
\text { utilis }\end{array}$ & $\begin{array}{l}\text { C. } \\
\text { glabrata }\end{array}$ & $\begin{array}{l}\text { C. } \\
\text { krusei }\end{array}$ \\
\hline V. cherianthifolium var. asperulum & 1000 & 250 & $>4000$ & 2000 & $>4000$ & 250 \\
\hline V. orygale & 125 & 250 & 125 & 250 & $>4000$ & 125 \\
\hline V. pycnostachyum & 1000 & 250 & 125 & 250 & $>4000$ & 62.5 \\
\hline Amphotericin B & 0.031 & 1.0 & 0.25 & 0.5 & 2.0 & 1.0 \\
\hline Ketoconazole & 0.008 & 0.031 & 0.031 & 0.25 & 0.25 & 0.25 \\
\hline
\end{tabular}

\section{RESULTS AND DISCUSSION}

\section{Cytotoxicity results}

The effects of V. pynostachyum, V. cheiranthifolium var. asperulum and $V$. orgyale methanol-extracts were assessed on HeLa (Figure 1) and Skov-3 (Figure 2) cells after 24 hours incubation with each extract using the MTT assay. The results obtained here indicated that all Verbascum $s p$. reduced the cell viability of both HeLa and Skov-3 cells in a dose-dependent manner. Particularly, the cell viability of both cell lines was significantly declined after treatment of $\mathrm{V}$. pycnostachyum extract as compared to other Verbascum $s p$. that cytotoxic effect was observed at lower concentration $(0.5 \mathrm{mg} / \mathrm{mL}-44.62 \%$ cell viability) on Skov-3 cells rather than HeLa cells $(0.5 \mathrm{mg} / \mathrm{mL}-71.54 \%$ cell viability).

V. orgyale methanolic-extract was shown a similar effect on both cell lines; HeLa ( $1 \mathrm{mg} / \mathrm{mL}-30.96 \%$ cell viability) (Figure 1C) and Skov-3 (1 mg/mL - 34.22\% cell viability) (Figure $2 \mathrm{C}$ ). On the other hand, a dramatic decrease in cell viability for HeLa was observed after incubation of $0.93 \mathrm{mg} / \mathrm{mL} \mathrm{V}$. cheiranthifolium var. asperulum methanol-extract (Figure 1B) as compared to the cell viability rate of Skov-3 cells treated with $2.01 \mathrm{mg} / \mathrm{mL}$ extract (Figure 2B).

The studies about the isolation of bioactive compounds have been reported that flavonoids, saponins, phenylpropanoid (12) and the phenylethanoid glycosides (22) were isolated although the type of bioactive compounds varies depending on the various Verbascum sp. Specifically, the isolation works on methanolic-extract and structure elucidation studies of $V$. pynostachyum were shown that it contained iridoids-glycosides, aukubin, ajugol, ajugosid, harpagoside, phenylethanoid glycoside and verbascoside (10). It has been reported that verbascoside has a hydrophilic character (19) and saponins (23) to possess anti-cancer and antimicrobial activity.

In this study, particularly $V$. pynostachyum species having a significant cytotoxic effect on Skov-3 cells that might be caused by the compounds such as verbascoside. However, in order to explain the relationship between activity-structure, it is necessary to determine the content of bioactive compounds of $V$. pynostachyum methanolic-extract.

\section{Anticandidal activity results}

Anticandidal activities of the methanolic extracts of $V$. cherianthifolium var. asperulum, $V$. orygale and $V$. pynostachyum were evaluated by using CLSI M27-A2 reference method. Tested Candida species were moderately inhibited by the extracts between the concentrations of the $62,5-4000 \mu \mathrm{g} / \mathrm{mL}$ (minimal inhibitory concentration). Remarkably, $V$. pynostachyum showed strong effects on Candida krusei having a MIC value of $62,5 \mu \mathrm{g} / \mathrm{mL}$. $V$. orygale and $V$. pynostachyum demonstrated better effects than Verbascum cherianthifolium var. asperulum against all tested Candida strains. All extracts were assumed to have the MIC values outside of the tested range against Candida glabrata ATCC 66032 (Table 1). In the previous study on Verbascum species, extract of the $V$. sinuatum $L$. showed anticandidal effect at the concentration of $32 \mu \mathrm{g} / \mathrm{mL}$ against $C$. albicans (25). In another study methanolic extract of the $V$. georgicum which have antimicrobial constituents reported as a novel antimicrobial raw material (6). According to a scientific review on bioactivities of Verbascum species, methanol and ethanol extracts showed strong inhibitory effects on Candida albicans and Gram (+) bacteria strains due to the their saponin content (26).

Today, especially in immunocompromised people, Candida infections causes major health problems. There are few available systemic antifungal drugs, additionally the rate of drug resistance is increasing dramatically to available drugs. The search for new natural antifungal agents against pathogenic Candida species is extremely important (24).

\section{ACKNOWLEDGMENTS}

The authors would like to thank Bio. Nur İpek Önder and BIBAAM for invaluable help in cytotoxic assay and lyophilisation. This study was supported by the Anadolu University, Commission of the Scientific Research Projects (No: 1304S069).

\section{REFERENCES}

1. Mabberley, DJ. Mabberley's plant-book (3th ed.). Cambridge University Press, Cambridge: XVIII , 1021, 2008.

2. Huber-Morath A. Verbascum L., In: Davis, P.H. (Ed.). Flora of Turkey and The East Aegean Islands, University Press, Edinburgh, Vol.6, pp 453-603, 1978.

3. Davis PH, Mill RR, Tan K. (Eds). Flora of Turkey and The East Aegean Islands (Suplement), Vol.10, University Press, Edinburgh, pp 190-2, 1988.

4. Karavelioğulları FA, Verbascum L. In: Güner A, Aslan S, Ekim T, Vural M, Babaç MT. (eds.). Türkiye Bitkileri Listesi (Damarlı Bitkiler). 
Nezahat Gökyiğit Botanik Bahçesi ve Flora Araştırmaları Derneği Yayını, İstanbul, pp 850-70, 2012.

5. Karavelioğulları FA, Yüce E, Bașer B. Verbascum duzgunbabadagensis (Scrophulariaceae), a new species from eastern Anatolia, Turkey, Phytotaxa 181 (1), 047-053, 2014.

6. Sengül $M$, Ögütçü $H$, Adigüzel $A$, Sahin $A$, Kara $A$, Karaman I, Güllüce M. Antimicrobial Effects of Verbascum georgicum Bentham Extract, Turk J Bot 29, 105, 2005.

7. Baytop T. Türkiye'de Bitkiler ile Tedavi, 2. Baskı, Nobel Tıp Kitabevleri, Istanbul, pp 334-5, 1999.

8. Tuzlacı E. Șifa Niyetine, Türkiye'nin Bitkisel Halk Ilaçları, Alfa Yayınları 1702, İstanbul, pp 379-383, 2006.

9. Senatore F, Rigano D, Formisano C, Grassia A, Basile A, Sorbo S. Phytogrowth-inhibitory and antibacterial activity of Verbascum sinuatum. Fitoterapia 78, 244, 2007.

10. Tatlı I, Schuhly W, Akdemir ZS. Secondary metabolites from bioactive methanolic extract of Verbascum pycnostachyum Bioss. Helder flowers. HU J Fac Pharm 27, 23-32, 2007.

11. Turker AU, Camper ND. Biological Activity of Common Mullein, A Medicinal Plant, J Ethnopharmacol 82, 117-125, 2002;

12. Klimek B, Stepien H. Effect of some constituents of mullein (Verbascum sp.) on proliferation of rat splenocytes in vitro, Eur $\mathrm{J}$ Pharm Sci 2, 123, 1994.

13. Lee JH, Lee JY, Kang HS, Jeong $\mathrm{CH}$, Moon JH, Whang WK. The effect of acteoside on histamine release and arachidonic acid release in RBL-2H3 mast cells. Arch Pharm Res 29, 508-13, 2006.

14. Alan S, Saltan FZ, Göktürk RS, Sökmen M, Taxonomical Properties of Three Verbascum L. Species Growing In Tukey and Their Antioxidant Activities, Asian J Chem 21, 5438-5452, 2009.

15. Quirantes-Piné R, Herranz-Lopez M, Funes L, Borrás-Linares I, Micol V. Segura-Carretero A. Phenylpropanoids and their metabolites are the major compounds responsible for blood-cell protection against oxidative stress after administration of Lippia citriodora in rats, Phytomedicine 20, 1112-8, 2013.

16. Abougazar $H$, Bedir $E$, Khan, IA, Çalış I, Wiedemannioside A-E: New Phenylethanoid Glycosides from the Roots of Verbascum wiedemannianum, Planta Medica 69(9) 814-9, 2003.
17. Mehdinezhad B, Rezaei A, Mohajeri D, Ashrafi A, Asmarian S, Sohrabi-Haghdost I, Hokmabad RV, Safarmashaei S. Comparison of in vivo wound healing activity of Verbascum thapsus flower extract with zinc oxide on experimental wound model in rabbits. Adv Environ Biol 5, 1501-9, 2011.

18. Dulger B, Kirmizi S, Arslan H, Güleryüz G. Antimicrobial activity of three endemic Verbascum species. Pharm Biol, 40, 587-9, 2002.

19. K orkina LG, Pastore S, Dellambra E, De Luca C. New molecular and cellular targets for chemoprevention and treatment of skin tumors by plant polyphenols: a critical review. Curr Med Chem, 20, 852-68, 2013.

20. Tatlı I, Akdemir Z.S. Cytotoxic Activity on Some Verbascum Species Growing in Turkey. Hacettepe University Journal of the Faculty of Pharmacy, 26:2, 77-85, 2006.

21. CLSI (NCCLS) M27-A2 Reference Method for Broth Dilution Antifungal Susceptibility Testing of Yeasts; Approved Standard-Second Edition, 2002.

22. Dembitsky VM. Astonishing diversity of natural surfactants: 5 . Biologically active glycosides of aromatic metabolites. Lipids 40, 869-900, 2005.

23. Riaz M, Zia-Ul-Haq M, Jaafar HZE. Common mullein, pharmacological and chemical aspects. Rev Bras Farmacog 23, 948-59, 2013.

24. Moran GP, Sullivan DJ, Henman MC, McCreary CE, Harrington BJ, Shanley DB, Coleman DC, Antifungal drug susceptibilities of oral Candida dubliniensis isolates from human immunodeficiency virus (HIV)-infected and non-HIV-infected subjects and generation of stable fluconazole-resistant derivatives in vitro. Antimicrob Agents Ch 41, 617, 1997.

25. Amin JN, Batool M, Abu-hadid Mahmoud M, Screening antibacterial and antifungal activities and evaluation of the exhaustive extractions yields for Verbascum sinuatum L., Int J Res Ayurveda Pharm 6(1), 2015.

26. Tatı II, Akdemir ZȘ, Traditional Uses and Biological Activities of Verbascum species, FABAD J Pharm Sci 31, 85-96, 2006.

Received : 04.02.2016

Accepted : 05.05.2016 